\title{
Collaborative Research Training Based on Virtual Spaces
}

\author{
Darío Rodríguez, Rodolfo Bertone, and Ramón García-Martínez
}

Programa de Maestría en Tecnología Informática Aplicada a la Educación,

Facultad de Informática, Universidad Nacional de La Plata, Argentina

Grupo de Investigación en Sistemas de Información. Departamento de Desarrollo

Productivo y Tecnológico, Universidad Nacional de Lanús, Argentina

Instituto de Investigaciones en Informática LIDI. Facultad de Informática,

Universidad Nacional de La Plata, Argentina

\{darodriguez, rgarcia\} @unla.edu.ar,

pbertone@lidi.info.unlp.edu.ar

\begin{abstract}
A possible strategy for training researchers is to provide integrated research cores with researchers-in-training under the guidance of a senior trained researcher. Information technology and communication have enabled the construction of virtual communities formed by individuals who may be far away physically but who are cognitively close, hence giving rise to collaborative research training models. In this context, this paper formulates an approach to identify the elements of the work space of a research group devoted to research training and to assess the technological feasibility of virtualization of such elements.
\end{abstract}

Keywords: Collaborative research training. Feasibility of researcher training virtualization.

\section{Introduction}

Several authors [1] [2] [3] [4] have noted that the research team can be made up of individuals who do not belong to the same institution or even the same country, and that the only requirement is that these individuals share the sense of belonging to a certain research group. Information technology and communication have enabled the construction of virtual communities formed by individuals who may be far away physically but cognitively close [5]. In this context, the massive use of the Internet demands a new conceptualization of notions such as research groups, research training, peer publications, socialization, and cooperation, among others. Virtualization has fostered the notion that groups are definitely not the sum of individuals but the result of a network of symbolic systems, practices, rituals and reflections. In this network of exchange of meanings among researchers regarding the object and the research project, a kind of virtual school is built where status is granted and research products are valued.

This paper introduces a possible theoretical framework (Section 2) in which the various definitions that the community has built upon research and projects (Section 2.1), training of researchers (Section 2.2) the concept of research communities 
(Section 2.3), and the relationships between interpersonal communication, researcher training and R\&D groups (Section 2.4) are presented. It also introduces a collaborative model for researcher training (Section 3) where the concept of research and research plan (Section 3.1) and the dynamics of the research group associated with the model (Section 3.2) are described in context. The technological feasibility of visualization of the model described (Section 4), identifying elements of the work space and their features, and exploring the technological feasibility of virtual work space by the construction of a web-based software artifact prototype is discussed. Finally, the conclusions and future lines of work are presented (Section 5).

\section{Theoretical Framework}

In this section, different aspects of the theoretical framework that the community has developed such as research, research projects, research training, research communities and their relation to the training of researchers are presented.

\subsection{Research and Projects}

Inciarte and Torres [6], propose that investigation is an ordering axis of research activity, having a rational basis and allowing for the integration and continuity of the efforts of one or more individuals, teams or institutions committed to the development of knowledge in a specific area. Its identification permits to establish levels of detail and specificity to address problems whose need to be solved is evident and shared. This, in turn, forms a teaching and learning scheme focused on research that has the following advantages:

[a] it promotes openness to criticize various unrestricted aspects or approaches to unique paradigmatic visions, convergence and divergence of concepts, approaches, methods and paradigms, dialogue, reflection and analysis of the deep and fruitful work of researchers-in-training. That is, openness to be observed by colleagues and strangers.

[b] it provides an excellent space to develop the research-learning process.

[c] it help to project the research allowing for an effective use of knowledge upon practice.

\subsection{Research Training}

Sánchez [7] argues that the training of researchers presents a pedagogical relationship in which three stages that will become the common axes of analysis may be identified:

[a] The interaction with the social environment (subjects and objects involved in the learning process).

[b] The individual appropriation or internalization on the part of the subject of knowledge generated by his/her research community.

[c] The transformation into the design of a project that is crystallized in a creation to solve a problem in one area of knowledge. 
Villarreal and Guevara [8] indicate that a possible strategy for training researchers is to provide integrated research cores formed by researchers-in-training under the guidance of a trained investigator with the following objectives: to collaborate with a project a senior researcher is developing and then generate his/her own project in collaboration with the senior researcher and under his/her guidance. In agreement with this, Moreno [5] proposes that the core of scientific research today are the groups (or communities) working around specific research projects. Moreover, is based on the fact that the preparation of human resources in research is closely related to the creation of an academic community, and hence to the development of knowledge [9]. In particular, the scientific communities express and embody epistemologies that circulate through fields and disciplines and that operate as a contextual indicator of the status of research training.

\subsection{Research Communities}

The lonely researcher is capable of generating knowledge, but is limited by the unidimensionality in training; then, the need to comprehensively approach reality is seen, and this requires various perspectives to be gathered in order to understand the subject. Hence, groups arose that are not a number of isolated projects put together, but a structure made up of individual interests trying to get acquainted with the same thematic area or nuclear problem [10].

Sánchez and Granados [11] define a research community constituted by: senior researchers, junior researchers, PhD students, advanced master students, and near graduation students. The research seminar (or workshop) is a practice established by the research groups to review the progress of their projects, so it becomes the natural structure that integrates this revision work. One of its advantages is its horizontality because it exceeds the traditional teacher-student relationship and fosters a relationship between colleagues. The collective space dynamics allows for autonomy spaces which conjugates the different experiences of all its members. It is a space of coconstruction, in which everyone learns, clarify their doubts and enrich projects with inputs from the group. The uptake of training by a researcher in a research community will benefit him because he has not yet acquired the same amount of information that trained investigators have as for instance personal collections of publications and a network of personal contacts with research expert fellows that can reduce the need for extensive information search, and therefore improve the use of information skills [12].

\subsection{Interpersonal Communication, Training and R\&D Group}

The communication promoted within a research community is a factor that favors the development of its members who, in permanent interaction subject+subject or subject+research-object, contribute with their expertise to solve problems. This interaction is mediated by knowledge and experience from both the academic and the professional world, which are significant to those who belong to a particular research community. Communication through group sessions, open spaces for senior researcher to consolidate the progress a researcher under training has made while the latter can benefit from the comments he/she makes to his peers as well as from peer observations. Through 
sharing and collaborating in research groups, an inter-formative relationship among its members is developed that turns them into co-construction spaces of knowledge which acquire a pedagogical value, since those who have access to methods and experiences developed by other researchers favors with the development of skills that are necessary for professional performance.

In this context, Moreno [5] indicates that the group provides a source that makes the relationship between the apprentice (young researcher) and the researcher (principal investigator) possible. The apprentice learns by comparing his emerging knowledge with the mature knowledge of other researchers, not only in terms of management tools, which is sometimes unfortunately most important, but also from the expert judgments, which represent the most sophisticated investigative learning. That is why during this process, the guidance and advice of a senior researcher is essential to correct and encourage the progress of a researcher under training. His collaboration is crucial, his knowledge and experience devoted to guide and strengthen the performance of novice researchers allows for the development of skills that lead them to make innovative projects and generate knowledge and technology [11].

\section{Collaborative Model for Research Training (MCFI)}

Rodriguez, Bertone and García-Martínez [4] propose a model for the training of researchers focused on collaboration. This model defines two aspects to be considered. First, the allocation of research topics, and second, the dynamics of group-oriented research to be "per se" an institution devoted to research training.

\subsection{Online Research and Research Plan}

The research group focuses on a senior researcher, who defines the research topics and generates the associated research plan. He establishes the research limits and determines the area of knowledge on which to apply the research plan. All members of the Research Group work in the same domain knowledge at different levels. The Senior Researcher assigns the research subjects ( $\mathrm{PhD}$ dissertation, Masters, Specialty or Grade) under different levels of implementation of research considering the following premises: Doctoral Thesis, which generates new knowledge within the domain established by trained investigators; Master Thesis, which establishes the manner in which the knowledge developed by PhD students can be applied to an advanced development (i.e.: Expert system); Specialty thesis, which involves a documental research project or an exploratory experimental work. This is linked to master and doctoral students. Grade Thesis, which develops a software artifact related to a master or a $\mathrm{PhD}$ research project. These relationships are illustrated in the diagram in Figure 1.

Within the research plan various research programs are generated, each linked in its origin to the proposal of a PhD student. For example, Figure 2 shows how the nodes marked in Figure 1 correspond to a real research program in which projects are related thesis of four different institutions.

These programs are mutually independent but are part of the domain knowledge associated with the research line defined by the senior researcher. 


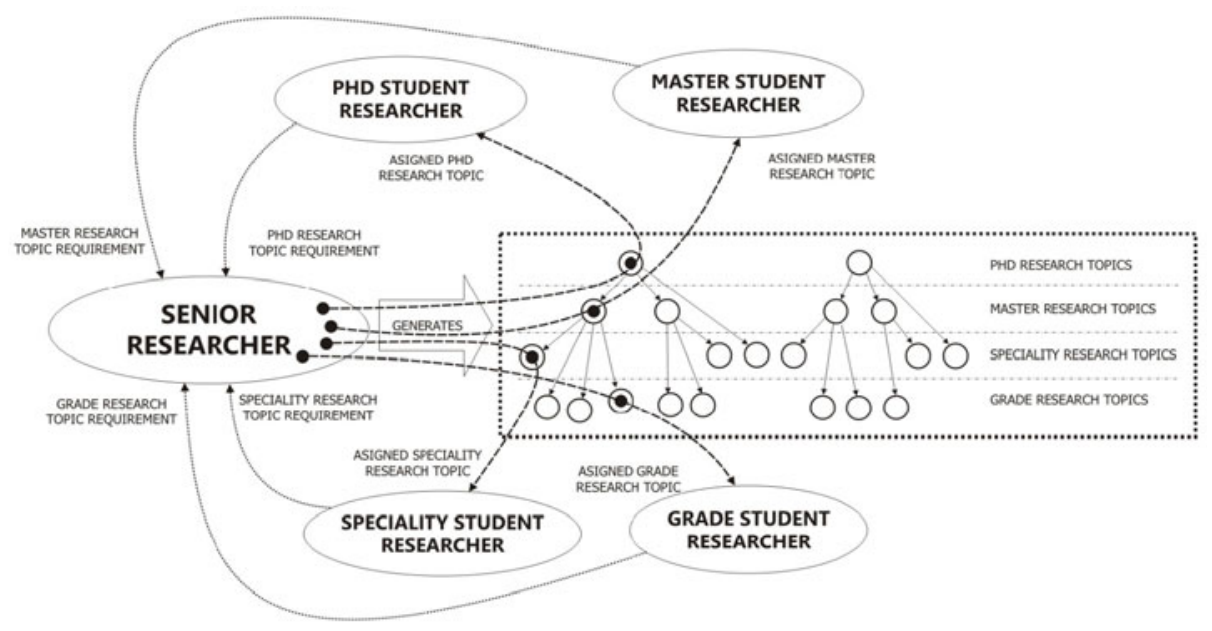

Fig. 1. Generation of research plan and allocation of research topics

PhD THESIS: Procesos de Explotación de Información Basados
en Sistemas Inteligentes [13]

Fig. 2. Real Research Program Example

The work of the master student completes the work began by the $\mathrm{PhD}$ student, thus generating his own project, chained to the doctoral student. This chain is completed by other theses of specialty and grade that are incorporated in the level immediately below the feeding chain and achieve the necessary feedback to verify and validate in real and concrete fields the doctoral student proposal.

\subsection{Research Group Dynamics}

As we move up the research levels, a general and global overview of the research process is obtained. The role of a senior researcher in the research process is to be a counselor and facilitator to the lower levels in the context of collaborative and participative learning [17]. The same research topic is approached at different research levels ( $\mathrm{PhD}$, Master, others), and in a natural collaboration an integrated process is achieved. The supervision takes place among high level training researchers interacting with immediately lower level training researchers. In comparison with the senior researchers, they are peers however they achieve research management and lower level researcher's contention [18]. 


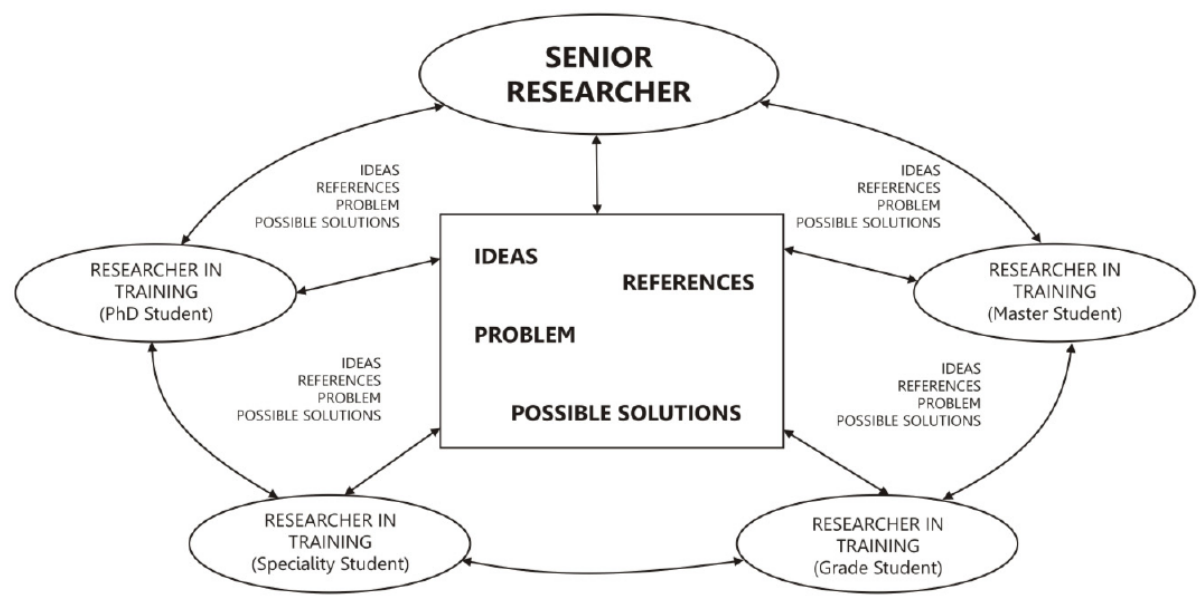

Fig. 3. Network of relationships in the researchers training collaborative model

The relationship network that guide the distribution of research tasks involves a circular collaborative network [19] that contains the senior researcher (see Figure 3) centered in ideas-problems-solutions-references associated with the various research problems, in opposition to the classical model (radial network) in which the senior researcher is in the center and researchers-in-training can only connect with him.

Under the cooperative and collaborative paradigm, the workshop or seminar of researchers-in-training coordinated by the senior researcher is the activity in which reviewing of research proposals occurs naturally and cooperation in seeking solutions for the emerging problems at each research project stage occurs naturally. In these meetings, each participant submits ideas, problems and possible solutions to the group and gets suggestions, criticisms and contributions of other members, under the supervision and guidance of a senior researcher. These tasks permits reporting the progress of each research project and receiving the corresponding feedback.

\section{Technological Feasibility of Virtualization (TFV)}

This section presents a developed work space which supports the collaborative model for research training in a distance teaching-learning manner. The work space has the following elements: a library of specialized publications, a repository of documents and a classroom where virtualized workshops or seminars are developed.

The classroom module is a virtual cooperation space where researchers can communicate in real time through video conferencing functionality using PC web cam and audio devices. The work space allows maintaining a channel of audio and video among multiple users simultaneously by using streaming video and voice over IP technologies. The researchers can exchange views and ideas in real time through a virtual whiteboard. Each member of the group can "draw" and make sketches, paste documents, images, and texts of any kind, while other participants see them in real time. This presents many challenges with respect to timing and transmission of data 


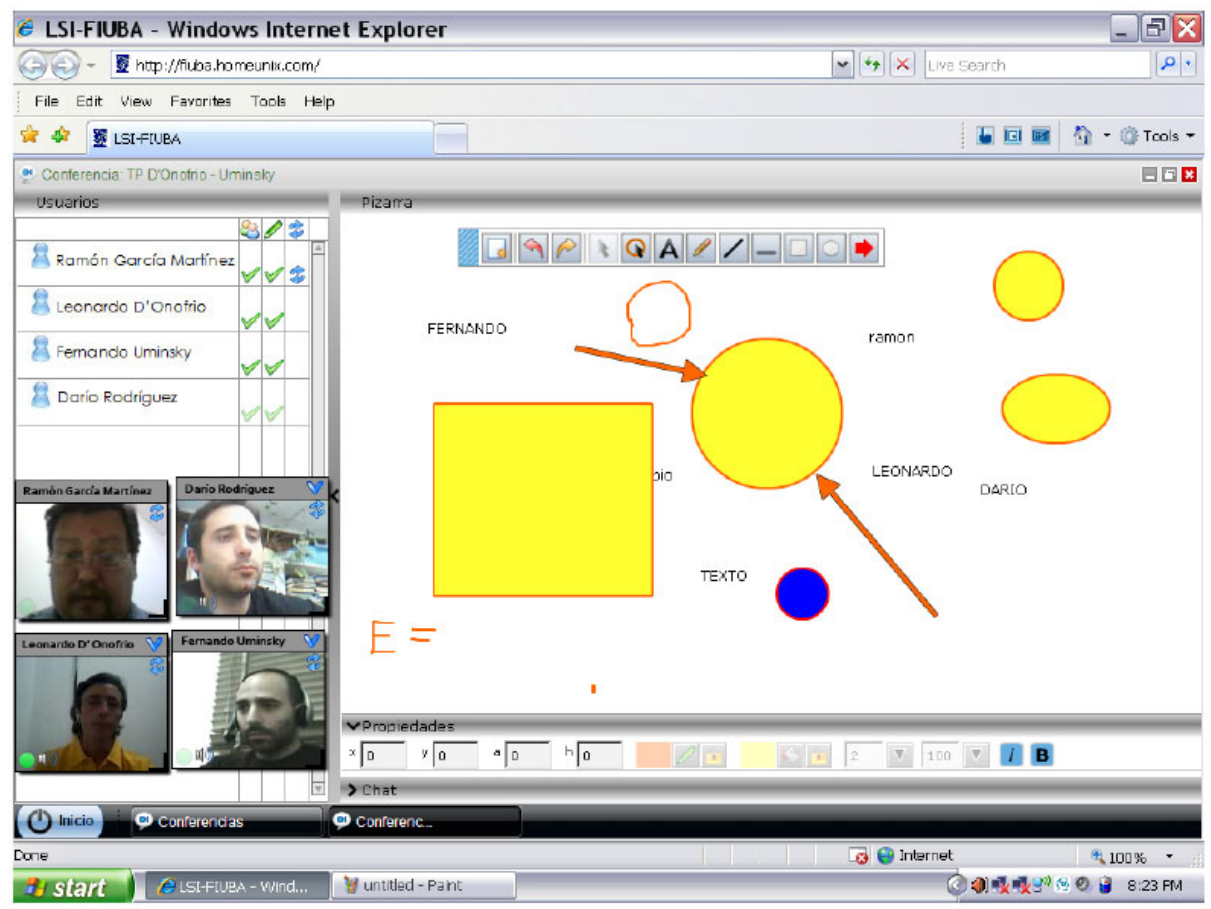

Fig. 4. Example of what a web cam based on communication and virtual whiteboard facilities looks like

among distributed programs and achieving the performance needed to ensure quality is still an open issue. Some example of free access artifacts that partially address the functionality of this module are "Skipe" [20] which enables web conference between two people and "Virtual Whiteboard" [21] which enables to share a web whiteboard among four people. Figure 4 presents what a web cam based on communication and virtual whiteboard facilities in the classroom module looks like.

The publication library module allows to managing specialized publications relevant to the domain of knowledge related to the research plan of the group in digital forms (journals, transactions and conference proceedings). Some example artifacts that are used to address this functionality are: "IEEE Computer Society Digital Library" website [22], "ACM Digital Library" website [23], and "Directory of Open Access Journals" website [24].

The document repository module allows managing two different groups of documents: the scientific production of the group (articles, communications, theses, task reports), and documents of interest from other research groups in the same domain. The documents may be stored by members of the research group in different formats and different types (i.e., text documents, spreadsheets, presentations, images, audio files, video files), be classified according to specified criteria and shared among members of the group of researchers. It also provides a search engine to facilitate the recovery of documents. Examples of some artifacts that address this functionality are: 
"UBA-FI-LSI" website [25] where $\mathrm{PhD}$, master and graduate theses, papers and conference communications are listed and access to them enabled, and "GRISE" website [26] which adds research reports (research documents) to previous example.

The intranet management module allows creating and managing research groups, users of the system, user profiles, permissions, parametric tables, documents, projects, scheduling conferences, and all functions necessary for the proper functioning of the platform dynamically.

\section{Conclusions}

The training of researchers involves interaction among persons who have different levels of professional and academic skills, on the one hand senior researchers and on the other hand various levels of trainee researchers. They constitute a community whose main activity is working on research issues within their discipline that become their focus of study.

Virtualization should allow for interaction among researchers located in different (and distant) geographical points, by creating a space to discuss research issues and exchange research documents that become the basis of virtual research groups.

We proposed a collaborative model for research training which is supported by a web-based collaborative software artifact. Besides, having a virtualized repository of scientific production of the research group constitutes the basis for two knowledge management tools, one being a record of the organizational memory and the other being a learning resource focused on a research topic. These tools ensure the flow of knowledge and work in a collaborative way inside the group.

Based on a balanced methodological model of higher education, we seek to identify technological media to virtualized training of researchers, making the needed resources that will help their learning process available to them; and making the senior researcher who guides them become a true facilitator for the acquisition of research skills.

The reality of our country (Argentina), with a few computer science research centers with capacity to train researchers at all levels, leads to the need of addressing the issue of alternative schemes for training researchers. The web communication technology for training researchers emerges as a possibility to set up research groups in which academic institutions with established research centers provide senior researchers while the rest of the university system provides the human resources to be trained in the research process.

In this context, this paper has explored the framework for research training, has introduced a scheme of collaborative training of researchers, and has presented a prototype of work space for the described virtualization scheme which runs in a single web software environment. On a following step, we expect to continue this work by defining the various related processes used by the collaborative scheme for training junior researchers, and to improve the developed software artifacts.

Acknowledgements. The Authors wish to thank Leonardo D'Onofrio and Fernando Uminsky who built the web-based software artifact (showed in Figure 4) used to prove the ideas presented in this paper. 


\section{References}

1. Rivera, B., Osorio, O., Tangarife, D., Arroyave, J.: Los Semilleros de Formación de Jóvenes Investigadores: la Experiencia de ASPA. Documentos en el Programa de Maestrías. Consorcio para el Desarrollo Sostenible de la Ecorregión Andina (2000), http: / / www . condesan. org/memoria/COL0700.pdf (available 11/07/09)

2. Ponce Rosas, R., Landgrave Ibáñez, S., González Salinas, C., Monroy Caballero, C.: Formación de investigadores en medicina familiar: La tutorización en investigación y la relación tutor-residente (Primera parte). Archivos de Medicina Familiar 4(2), 77-81 (2002)

3. Padrón Guillen, J.: Los 7 Pecados Capitales de la Investigación Universitaria. Informe de Investigaciones Educativas 18, 69-79 (2004)

4. Rodríguez, D., Bertone, R., García-Martínez, R.: Consideraciones sobre el Uso de Espacios Virtuales en la Formación de Investigadores. Revista de Informática Educativa y Medios Audiovisuales 6, 35-42 (2009)

5. Moreno, M.: Dos Pistas para el Análisis de los Procesos de Formación de Investigadores en las Universidades Colombianas. In: Nómadas. Instituto de Estudios Sociales Contemporáneos. Facultad de Ciencias Sociales Humanidades y Artes, vol. 7, pp. 38-48. Universidad Central, Colombia (1997),

http: / / www . ucentral . edu.co/NOMADAS/nunme-ante/610/ nomadas_07/revista_numero_7_art07_hacia_una_propuestas.pdf

6. Inciarte, A., Torres, M.: La línea y los grupos de investigación, de investigación como estrategia para la formación de investigadores. Agenda Académica 6(1), 23-28 (1999)

7. Sánchez, L.: Formación de investigadores en posgrado. Un proceso pedagógico por atender. In: XX Congreso Nacional de Posgrado, México (2006),

http: //www. cenidet. edu.mx/subaca/webdda/docs / leticiacomepo06.pdf (available 11/07/09)

8. Villarreal, D., Guevara, J.: Una Experiencia en Formación de Investigadores. In: Núcleos de Investigadores en la Universidad Autónoma de Tamaulipas. Revista de la Educación Superior, Número 92. Asociación Nacional de Universidades e Instituciones de Educación Superior, vol. XXIII(4) (1994),

http://www.anuies.mx/servicios/p_anuies/publicaciones/revsup /res092/txt1.htm (available 11/07/09)

9. Serrano, J.N.: se Hacen o los Hacen: Formación de Investigadores y Cultura Organizacional en las Universidades. In: Nómadas. Instituto de Estudios Sociales Contemporáneos. Facultad de Ciencias Sociales Humanidades y Artes. Universidad Central, Colombia, vol. 7, pp. 52-62 (1997),

http: / / www . ucentral . edu. co/NOMADAS / nunme-ante / 610/nomadas_07/revista_numero_7_art04_nacen.pdf (available 11/07/09)

10. Agudelo Cely, N.: Las Líneas de Investigación y la Formación de Investigadores: Una Mirada desde la Administración y sus Procesos Formativos. In: Revista Electrónica de la Red de Investigación Educativa, vol. 1(1) (2004) ISSN: 1794-8061,

http: / / revista. iered. org/v1n1/pdf / ncagudelo.pdf (available 11/07/09)

11. Sánchez, L., Granados, M.: Experiencias de Autoformación y Heteroformación de Formadores de Investigadores en el Campo Tecnológico. In: IX Congreso Nacional de Investigación Educativa, México (2007), http://www. comie.org.mx/congreso/memoria/v9/ponencias/at16/P RE1178923303.pdf (available 11/07/09)

12. Barry, B.: Information skills for an electronic world: training doctoral research students. Journal of Information Science 23(3), 225-238 (1997) 
13. Britos, P.: Procesos de Explotación de Información Basados en Sistemas Inteligentes. Tesis de Doctorado en Ciencias Informáticas. Facultad de Informática. Universidad Nacional de La Plata (2008)

14. Merlino, H.: Ambiente de Integración de Herramientas para Exploración de Datos Centrados en la Web. Tesis de Magister en Ingeniería de Software. Facultad de Informática. Universidad Politécnica de Madrid (2006)

15. Césari, M.: Nivel de Significación Estadística para el Aprendizaje de una Red Bayesiana. Tesis de Especialidad en Tecnologías de Explotación de Información. Insttituto Tecnológico de Buenos Aires (2006)

16. Schulz, G.: Un Ambiente Integrado de Clasificación, Selección y Ponderación de Reglas Basado en Sistemas Inteligentes. Tesis de Grado en Ingeniería Informática. Laboratorio de Sistemas Inteligentes. Facultad de Ingeniería. UBA (2008)

17. Duart, J., Sangrà, A.: Formación universitaria por medio de la web: un modelo integrador para el aprendizaje superior. In: Duart, Sangrà (eds.) Aprender en la Virtualidad, Gedisa, Barcelona (2000) ISBN: 84-8429-161-8

18. Moreno Aguilar, L., Vargas Solar, G., Sheremetov, L.: Hacia una infraestructura de componentes para la construcción de ambientes de aprendizaje colaborativo. In: XIX Simposio Internacional de Computación en la Educación. Contextos emergentes en el aprendizaje. SOMECE 2003, México (2003),

http: / /bibliotecadigital. conevyt.org.mx/colecciones / document os / somece/59.pdf (available 11/07/09)

19. Valerio, G.: Herramientas Tecnológicas para la Administración del Conocimiento. Transferencia 57, 19-21 (2002),

http://www.sistemasdeconocimiento.org/Produccion_intelectual /articulos/herramientas_km.pdf (available 11/07/09)

20. SKYPE. Sitio Oficial para Descarga de SKYPE (2009), http: / / www.skype.com/intl/es / (available 11/07/09)

21. Virtual Whiteboard. Virtual Whiteboard - A Free Online Collaboration Tool (2009), http: / / www. virtual-whiteboard. co.uk/home.asp (available 11/07/09)

22. IEEE. IEEE Computer Society Digital Library (2009), http: / / www2 . computer.org/portal / web/ csdl / home (available 11/07/09)

23. ACM. ACM Digital Library (2009), http://portal .acm.org/dl . cfm (available 11/07/09)

24. DOAJ. Directory of Open Access Journals (2009), http: / /www. doaj .org/ (available 11/07/09)

25. UBA-FI-LSI. Laboratorio de Sistemas Inteligentes. Facultad de Ingeniería. UBA (2009), http://laboratorios.fi.uba.ar/lsi/z-hemerotecavirtual.htm (available 11/07/09)

26. GRISE. Grupo de Investigación en Ingeniería de Software Empírica. Facultad de Informática. UPM (2009), http: / / www. grise.upm.es / (available 11/07/09) 